\title{
THE BRODHEAD DIARIES 1846-1849
}

\section{BY DAVID POTTER}

Dr. POTTER, a graduate of Rutgers in the Class of 1937, is the author of Debating in the Colonial Charter Colleges: An Historical Survey 1642-1900. This article is based on his reading of a group of American manuscript diaries and letters which came to the Library a few years ago.

7 HE reputation of John Romeyn Brodhead (Rutgers, A.B. I 83 I ; A.M. I 834 ; LL.D. I 862), and trustee of the College from I 853 to I 873 , has been founded largely upon his
monumental History of the State of New York, his procuring and transcribing of documents relating to the colonial history of that state (an achievement which prompted George Bancroft to remark: "The ship in which he came back was more richly freighted with new material for American history than any that ever crossed the Atlantic."), ${ }^{1}$ and other meticulous historical research. Brodhead's service in the diplomatic corps has, however, received little attention. This is unfortunate, for the diaries of $1846-1849$, the period in which he acted as Secretary of the United States Legation to the Court of St. James under Bancroft, present an intimate glimpse of the personalities, politics, and culture of the period. For example, biographers of George Bancroft will discover in the diaries weighted information about their subject and his wife. Thus on Tuesday, 7 March, I 848, we find Brodhead complaining:

An incident occurred today of an unpleasant character. Thomas came into the office about 2 o'clock... with a message that Mrs B. wished me to send up two cards one for the H. of L. \& one for the H. of L. without any date for Mr [Ralph Waldo] Emerson. I told T. I would myself go up . . \& \& see Mr E. I went up-E. Mrs B. \& a lady in black on the sofa. After saluting Mr E. I said I would be happy to furnish him with tickets-when Madame in what I thought a dictatorial manner desired me to leave the dates blank. I said I should put dates on the cards, \& then told $\mathrm{Mr}$ E. if he would stop in the office I would give them to him. He came down \& I gave him cards for this evening with dates $-\& 2$ others without to fill up as he wished. I acted thus on principle as I did not think it was becoming for Madame to send such a message to the Secty of Legn.

At dinner time, I came in to see if the Washington's bag had come. . . . Madame asked me if I had given $\mathrm{Mr} \mathrm{E}$ cards with dates. I said yes-\& also a couple without. Shortly after . . Mr B began in a joking way . . . to tell

${ }^{1}$ Scribner's Monthly Magazine, XIII (February, 1877), p. 460. 
Mad. that she interfered too much in the Legation $-\&$ that he and I got along very well together-She became very angry....

These petty annoyances of Mrs B. are trying. Mr B. \& I get along very well together-but I can't stand it to have her interfere so- \& I will resign $\&$ go home rather than have it continue.

Brodhead did not resign and on Sunday, r9 March the diary reveals: "Dined with Mr \& Mrs B. at Eaton Sq. with Emerson, \& had a delightful time." Two months later, however, the cordiality which had been re-established was strained by the news that the Bancrofts had invited another member of the official family to a dinner to which Brodhead's presence had not been requested. The diary for Io May contains this pointed reference: "Dam-'d Yankee!!!"

The relationship between the Bancrofts and the Secretary of the Legation was not, henceforth, characterized by untoward animosity. The diary for 20 July, I 848 informs us, nevertheless:

The Bancrofts came home this noon. . . I I was very glad to see them back - but somehow or other, I do not feel that warm regard for them that I did before I knew them well \& intimately-They are ingrainedly selfish people. And Madame a very vain smart \& pretty Yankee Woman whose head is quite turned by the attention her husband's position here commands. She seems to "wind herself up for the day" . . and talks evidently for effect-to sustain her reputation for cleverness-which she certainly has more than even the Mass of Yankee Women-My relations with him are kind \& courteous-but I certainly think he does not show that kindness of heart that Everett did\& considering my official connexion he is apparently quite indisposed to do what is proper. He has not even introduced me to several members of the Govt. as etiquette requires - \& has evidently made up his mind to keep me in the office as much as possible to let him ramble....

Although Brodhead believed that he was regarded by the Bancrofts more as a menial than as an important member of the Legation, he was present at many of their elaborate affairs. For example, on Friday, 26 February, 1847 , the diary reveals:

Mrs B's grand dinner came off today. ... Madame \& I were occupied a good part of the morning in making all the arrangements \& what is rather strange they all came out right. We had Hon Miss Murray, Mr \& Mrs Carlyle, Mr \& Mrs Wormeley, Miss Wormeley Mr Davis, Mr \& Mrs Pell, \& ourselves. Carlyle as usual talked paradoxes \& I must say appears better at a distance than as a talker on terms. 
Again on Wednesday, 25 August, I 847, he notes:

Dined today with Mr \& Mrs B. McGregor \& Lady Sidney Morgan were there- $\&$ in great spirits. She told us several anecdotes about herself $\&$ especially about her writing the famous song Kate Kearny! Her anecdotes of Louis Philippe \& other distinguished people were piquante \& very interesting.

Throughout I 848 and I 849 , however, Brodhead does not miss an opportunity to tarnish the reputation of his "Yankee" hosts. Thus on Tuesday, 8 May, I 849, we read:

Breakfasted this morning ... with the Bs-Had Duke of Argyll, Macaulay. ... It was delicious. Macaulay in a blaze of rhetoric kept us in admiration for 2 hours. All were in good [illegible word] except the B's-who appeared constrained \& oppressed. Why is this? They [illegible word] clever peopleboth shrewd \& acute Yankees-but nobility doth dark even loud mouthed democracy sometimes.

Disapproval of the Bancrofts did not prevent Secretary Brodhead from discharging his many official duties, one of which was representing American authors in England. Acting in the capacity of literary agent for Herman Melville, he writes on Thursday, i 8 February, I 847:

Recd Hamden's letter, stating that Melville's proof sheets of "Omoo," had been seized by the C. H. at Liverpool, as a piracy. I wrote at once a pretty sharp letter to Hamden, desiring them to free the parcel and send it to Miller.

On Saturday, 20 February, Brodhead notes with satisfaction:

Recd Hamden's reply that my letter had been received and that the C. H. officer had discovered his error $-\&$ had released the Book $-\&$ requested to have his offense overlooked.

Enclosed the proof sheets to Murray with a note requesting his early attention.

On Thursday, 25 February, Brodhead again called on Murray and the following day the diary announces:

Recd Murray's proposition about Herman Melville's Book-“"Omoo"-he offers for the Copyright $\mathfrak{E}_{150}$-in a note of 8 mos from I April-when he proposes to bring it out. I think the terms not liberal enough, \& yet I shall have to take them I suppose.

Although Typee had drawn only $£_{1} 00$ from the English publisher the preceding year, ${ }^{2}$ Brodhead was loath to accept Murray's

${ }^{2}$ Minnigerode, Meade, Some Personal Letters of Herman Melville and a Bibliography, New York: The Brick Row Book Shop, Inc., 1922, p. 105. 
terms. Consequently, he again accosted the publisher and apparently argued that the excellent reviews given Typee in the British and American periodicals warranted $O$ moo a more generous offer. This line of reasoning was unsuccessful as the diary for Saturday, 27 February reveals:

He [Murray] said that so far from Melville's first Book helping the sale of the second, he hoped the reverse would be true, for he had not yet sold enough of the first to pay expenses. It was then agreed that I should write to him \& he would reply as to cash payt-

On Tuesday, 2 March, I 847, Murray accepted terms and on the 3oth of the month, the diary informs us: "Melville's Book published today-\& Murray gave me his check for $\mathfrak{E}_{\mathrm{r}} 44.3 .4$ which I gave to Miller to deposit with Barrings to meet Mr Melville's draft. . .."

When the proof sheets of Melville's next book, Mardi, arrived in England, Brodhead again acted as literary agent. On 24 February, I 849 the diary reads:

Made several calls-and then came home \& read Melville's new work "Mardi"-which as Murray has declined it, I am now to offer to Bentley as Melville's agent. It is a fiction \& Mr Murray says it don't suit him.

Although Brodhead's diaries indicated that he read contemporary literature like Vanity Fair in addition to Omoo, Mardi, and other American works, they seldom indicate his reaction to the reading matter. He was, however, much more explicit in regard to the plays which vied with the opera and the Royal Institution for his weekday after-dinner hours. Entries throughout his entire stay in England abound with references to the outstanding performers and "hits" of the period. The following are typical:

Thursday, $4^{\text {th }}$ March [1 847] ... went with Johnston \& his wife (Celeste's daughter) to the Adelphi, to see the "Green Brushes"-The acting was exceedingly good. Wright, Celeste, Harding, \&c-

Friday, 5 March. This evening went with Johnston to the Haymarket. Saw "The School for Scheming - and the Invisible Prince-Met Celeste, Webster, \&c-

Thursday, I I March ... saw a new drama written by Buckstone performed - called the "Flower of the Forest"-This drama was very well received for its first night-and all played their parts very well—upon the whole one of the most effective dramas I ever saw- 
Tuesday, $26 \mathrm{Oct}^{\mathrm{r}}$. This evening went to the Haymarket, \& saw Taming of the Shrew produced-in Shakespere's words-Introduction \& all. It was quaint \& amusing — \& Mrs Nisbett \& Webster and Keeley played admirably-

Wednesday, I9 Jany [ I 848 ]. In the Evg went to the Haymarket \& saw the Keans triumph in the "Wife's Secret." It is the best modern drama I have seen.

Monday ro July. This evening went to Drury Lane to hear Macready in his favorite benefit. The Queen was there in State, also altogether it was a very magnificent scene-The first three acts of Henry VIII and the Jealous Wife (Colman's) were the pièces de resístance; and Macready evidently did his prettiest. I never saw him so full of life before.

As we see, Brodhead was not afraid to use superlatives but he outdid himself in recording his impressions of the Shakespearean benefit given on Tuesday night, 7 December, I 847 :

I have had the greatest Theatrical treat of my life-or that I ever expect to have. In aid of the funds for the purchase of Shakespere's House, the Committee gave a great entertainment at the Italian Opera House . . consisting of selections from the best of Shakespere's plays- $\&$ by the best actors. Accordingly Lawrence \& Peabody \& I after dining ... went down-the House was very full--but we were fortunately placed near the orchestra and had a fair view. The audience (part of it) was noisy at first, \& prevented the prologue by Phelps being heard at all. He began twice "The Macedonian"but stopped short. We had extracts from Henry IV-by Macready Leigh Murray \&c-2. Death of Queen Catherine by Mrs Butler \&c-3. Lance \& Spear from Two Gentlemen of Verona by Harley \& Buckstone-4. Falstaff recruits \&c by Farren, Eranby, Oxberry \&c-5. Juliet's Marriage day, by Miss Helen Faucit, Mrs Glover \&c. 6. Katherine \& Petruchio by Mrs Nisbett, Webster, Keeley, Howe, Vandenhoff, \&c-7. The Buck basket \& Slenders wooing-from Merry Wives_by Madame Vestris . . . Charles Mathews. . . . 8. Prospero's Story-by Phelps, Miss Addison, Miss Horton ... and 9. the statue scene from Winter's Tale, by Graham, Vining, and Mrs Warner, \&c-Altogether it was the greatest theatrical treat that the age could produce-All the great artists (Miss Cushman \& the Keans excepted) being engaged - and all playing with unction-Harley \& BuckstoneWebster, Mrs Nisbett \& Keeley, Farren Miss Horton, \&c were all called out after their scenes, and the audience was in very good humor. The Theatre was crowded from top to bottom-and upon the whole, the arrangements were quite good. . . . Dickens, Bancroft \& several more I saw were present-

Although the diaries are more concerned with personal affairs and the pursuit of culture and entertainment than with international and 
continental politics, we do find many pertinent references to topical incidents. Thus:

Thursday 30 Sept [1847]

This morning received the Caledonia's Bag. The news of Scott's victory in front of Mexico is pretty cheering though as usual the papers here are unjust-

Wednesday 17. Nov. [1847]

Busy all day at the Office preparing Mr B's admirable Dispatch No 52 on the Navigation Law. It will do much good to the Free trade doctrinaires at home-

Friday 25 Feby [1848] ... saw the news of the Revolution in Paris ... $\mathcal{E}^{\circ}$ the Establishment of a provincial government with a strong tendency to a Republic. Louis Philippe has now got his reward for his crimes.- "The selfishness of evil defeats itself \& Providence rules in the affairs of men."

Wednesday, I March [1848]

Went today to the Service which was attended by all the Corps dip-except the French. ... I I find that the Corps unanimously condemns Mr Rush's conduct at Paris in going so precipitably to the Hotel de Ville to salute the Provisional govt. They say he was the youngest of the corps-that he thrust himself forward without concert with his colleagues contrary to Diplomatic usage \&c \&c-All this would be very well if Mr. R. like the rest of them represented monarchies. But the case is different here-The sympathies of America are with the new order in France. Mr R. only anticipated what will certainly be the universal sentiment of America — \& he will be fully sustained in all he has done, however contrary it may be to the regular etiquette of diplomacy.

Wednesday. 8 March [1848] ... on passing near Trafalgar Square saw a large crowd gaping at the Police-A strange $\&$ foolish demonstration if it may be worthy the name-and utterly without object or purpose- "They do things otherwise in France"-

Beginning in June, 1848 , the diaries indicate a growing concern over the home political scene. A Cass supporter and, apparently, slated for a political plum if his favorite won the election, Brodhead scanned the American dispatches with great anxiety. The changes in his political career are mirrored in these extracts:

Wednesday I4 June [ I 848]-Glorious day! Heard the News that Cass was nominated at Baltimore. It came up by Telegraph and pleased me as much as I fancy it did not my chief- 
Friday 23 June [1848]

Coming home with a bad headache I found the wind had blown down a large mirror in my room \& smashed it to atoms-a presage of ill luck-\& Just before I went to bed letters were brought me-from Campbell-\& \&cby the United States-Taylor nominated-\& Cass no chance.

Monday, 25 June [1849]-Received the Bag today, and Letters from N. Y. in which it is said that ... a son of my friend "Honest John Davis," is to be the new Secy of Legation. This is one account-I do not believe it-(though Madame does) for when D. left us last autumn I shook his hand in the cab at the door- $\&$ in answer to a jocular remark about his not voting against me in the Senate, should the P. [resident] send me to R [ome]-- "Depend upon it R-if I can't help you, I shall certainly not do you harm"

Madame was right! On Wednesday, I August, I849, the diary reveals that Brodhead "occupied all the morning inducting Davis into the office" and on Friday, 3 August, his final entry reads: "on board Southampton at Spithead. The Captain came on board at 2 . \& at 4 o'clock we got our anchor up, \& stood out by the port light - the wind N.E. \& steady-" 